By RUBY ETHEL CUNDIFF

\title{
The Use of Records in College Teaching
}

Miss Cundiff is assistant professor, George Peabody College for Teachers, Library School, Nashville, Tenn.

THE USE OF RECORDS in college teach1 ing is one part of audio aids in general. It may be definitely tied up with radio broadcasts, with broadcasting, and certainly with the making of transcriptions.

Records have some advantages over radio. For example, a record is available whenever the teacher wants to use it. It can be used over and over again while a radio feature comes at a stated time which may not even coincide with a meeting of the class. Also, the radio program is over in a few minutes and will not be repeated in just the same form. Another advantage of the record over the radio is that the teacher can be sure beforehand just what is to be given and can make whatever preparation is desirable ahead of time.

If the radio has a sound recording attachment, transcriptions can be made from any radio program which will be wanted at some future time, and that will make it possible to have that particular program whenever it is wanted and it may be repeated as often as it is needed.

A great deal of experimenting has been done in the elementary school, the high school, and some in college in the use of records in courses of study. Schools which have made the most use of records indicate the following fields in the order of use: music, language and literature, social studies, and science.

Reports of Three Studies of Record Use

Samuel Weingarten ${ }^{1}$ reports an experiment which was made in the use of Shakespeare records. Records made by actors in different periods from the romantic age of Marlowe and Sothern to the modern times of John Barrymore were played. The students gained an understanding of the plays as written for stage production and a realization that the reading, not the scenery, was most important in suggesting images. A change in appreciation brought about by the movies seemed to be the reason for the students preferring modern Romeo versions to the very excellent but to them stilted Sothern rendition. It was an excellent method of encouraging critical study of the plays, far better than reading any amount of written criticism or than trying to answer any number of questions as to how a given speech should be interpreted.

Mr. Weingarten includes a list of about fifty phonograph recordings of Shakespeare readings or plays with the prices of separate items.

The purpose of using recordings is to make instructional material more real,

1 Weingarten, Samuel. "Use of Phonograph Records in Teaching Shakespeare." College English I : 45-6r, October I 939 . 
vivid, or impressive. If it does this, greater retention should be expected and this was found to be true in a study reported by Phillip J. Rulon and others. ${ }^{2}$ It indicated that immediate acquisition of knowledge was quicker by reading but that longer retention and better understanding was the result of the use of records.

- Miss Hauck ${ }^{3}$ wrote an excellent account of the use of phonograph records at Blackburn College. In addition to their use in her own school she queried other colleges which also had Carnegie music sets.

\section{Care and Treatment of Records}

The Joint University Libraries (Peabody, Scarritt, and Vanderbilt colleges) own a Carnegie music set. There is a catalog which accompanies the records and this is a boon to those libraries which have Carnegie sets. For other record collections there has been no standardized method of care, but the Music Library Association has prepared a "Code for Cataloging Phonograph Records"' which will make for uniformity in the future. Some small collections will not use as much detail as is given in the code; however, it will help them get uniformity. A number of libraries have developed their own systems, which have been published in mimeographed form.

Union College and Skidmore College, among others, have good collections of records with specially made cases for their care. They keep their records flat rather

${ }^{2}$ Rulon, Phillip J., and others. "A Comparison of Phonograph Recordings with Printed Materials in Terms of Knowledge Gained Through Their Use Alone." Harvard Educational Review I $3: 63 \cdot 76$, Jan-

uary r943. Helen G. "The Use of Phonograph Records in the Junior College." College and Research Libraries 2:327-3 I, September I94I.

"Music Library Association. "Code for Cataloging Phonograph Records." I942. (This is a section of a larger "Code for Cataloging Music.") than standing on edge in albums, as the latter treatment tends to warp the record after a period of time.

Some collections of records are built up in the library, while others are made by the departments interested. It seems unfortunate to divide collections since many of the records will be useful to more than one department, just as the same books are often used in several subject fields.

When records are housed in the library they are sometimes restricted to a special soundproof room adapted to their use. Sometimes they are loaned to classes or individuals to use at their pleasure. Illinois State Normal University Library provides a special room, and classes are brought there to listen to the records. The Joint University Libraries have three small rooms in which records can be played. Records have circulated freely to anyone authorized by special professors until recent months when it was decided that "for the duration" records must be used in the library rooms on account of the difficulty if not the impossibility of replacing worn-out records. Also, if records are used in the library, there can be control as to the kind of machine, the condition of the needle used, etc., which insures the best care of the record while it is in use.

\section{George Peabody College for Teachers Pioneers}

George Peabody College for Teachers has pioneered in the development of a record collection, especially for one for the use of college and graduate students working in the demonstration school of the college. Milton L. Shane (now in the armed forces) has taught a course in audio-visual education and has built up a 
collection of materials housed in the demonstration school correlated with but not yet made an integral part of the library.

In visiting a first-year high school French class recently a record was heard. It was not the parts of a verb nor was it an exercise spoken slowly to show the value of certain sounds, but it was a French song sung by a group of French children. The high school freshmen listened to the song which they had studied earlier, then they joined in with the children singing on the record.

A senior high school class listened to several Shakespeare records while studying Macbeth.

\section{Readings on Records}

The Peabody College Library, in addition to the collection housed in the demonstration school, has a number of records for the use of classes in modern languages, English, French, and German literature, records for appreciation of poetry, and readings from and by the modern poets. Unique records in this collection are readings from Chaucer by Walter Clyde Curry, of the Vanderbilt University faculty, and by Charles B. Pendleton, of the faculty of Peabody College. They have also done readings from Beowulf. The records sponsored by the National Council of Teachers of English include readings from Chaucer and Beowulf, which students compare with those by the local professors who are authorities in this literary field.

Susan B. Riley, of the Peabody faculty, made some recordings under the title "Poetic Portraits and Poems on Beauty." These include classic and modern poetry.

The modern languages department uses records for an understanding of sound values and also to test comprehension of the language when spoken at a normal rate of speed. The head of the department reports that he feels that they are not using records as much as they should.

English classes listen to poetry read by the poets and by outstanding readers of the poets' words. They hear records from noted Shakespeare actors. The department makes recordings also.

\section{In Physical Education Department}

The physical education department uses records for special purposes only. When students are learning a rhumba they use a record because it is difficult to get a student accompanist who can play for them. When preparing for the spring dance festival it is difficult to get the full orchestra of the college for constant practice; therefore, they use orchestral records for daily practice and have the orchestra only a few times before the final performance. When working with beginners the instructors find it better to have an accompanist who can stop and wait for an explanation or who can regulate his speed to the ability of the group, than to use a record. With advanced students, on the other hand, the record is frequently more satisfactory.

The biology teacher used a collection of bird songs in a class at the demonstration school when teaching a unit on birds.

The speech department puts on a number of plays during the year and uses excerpts from plays much as the Shakespeare readings were used in the Weingarten experiment. Both the speech and the foreign language departments use transcriptions of students' voices in order to help students understand how their voices really sound and to help them overcome any speech defects either in English 
or in the foreign language being studied.

The department of music at Peabody uses records a great deal in music appreciation, in history of music, and in a survey of modern music. It also uses records in studying orchestration: in seeing how a man writes music and in conducting, that is, in learning how to conduct an orchestra. There is a collection in the music department library (cataloged in the main library), and the instructors borrow many records from the Joint University Libraries. Listening periods are assigned in some classes, and records are played during class periods as well. Students listen individually and in groups whether records are assigned or not. The records in the Joint University Libraries collection are used constantly, as well as those in the music department library.

\section{Sources and Appraisals of Records}

An excellent publication ${ }^{5}$ lists records for educational purposes. There is an introduction on the value and use of recordings and on the preparation and organization of the catalog. The main body of the publication is taken up with listing; general rating (fair, good, etc.) ; level for which suitable (high school, college, etc.) ; study aids for the record, if any; and appraisal of the record. The arrangement is by large subject groups: social studies and science, English literature and speech, foreign language, elementary school programs, and a miscellaneous list. The appendix gives instruction on how to operate a recording player and how to evaluate an educational recording. A list of producers and distributors of recordings is also included. An alphabetical index by author, title, and subject

5 Recordings for School Use, I942. World Book Co., New York, 1942. (Radio in Education Series.) of each record makes it possible to locate a special item easily.

Mr. Shane ${ }^{6}$ lists the equipment needed for an audio-visual room, which costs more than one thousand dollars. This is for equipment for radio, motion picture, and records, of course, but it is only apparatus, not materials. If only a records room were set up it would cost less than one thousand dollars for equipment, but materials would add a considerable amount. Unfortunately at the present time both materials and equipment are difficult or impossible to obtain; nevertheless, it may be well to plan and to put aside money now to be used for a record collection in college teaching after the war.

\section{Conclusions and Recommendations}

Since Peabody College is still in the trial and error stage in the use of records, it is not to be wondered at that records are scattered considerably and that the plan for their use is not uniform. A plan is under consideration to keep all equipment in a laboratory and to schedule classes there to hear programs requiring equipment that is difficult to move or which will be injured if moved by persons unfamiliar with its handling. Small record-playing machines may be moved to classrooms, if for any reason this makes a better learning situation. One central place should have a catalog of all records in the Peabody College Library, the Joint University Libraries, and the demonstration school.

A uniform system of support needs to be worked out. Records could well be (Continued on page 332)

'Shane, Milton L. The Audio-Visual Library: An Acquirition Plan. Peabody Library School, Nashville, Tenn., r940. (Peabody Contributions to Librarianship.) Reprinted from the Peabody Jour nal of Education, July 1940. 
medicine (exclusive of works published before the nineteenth century, tropical veterinary medicine, and popular works).

Mr. Miller listed as the "special collections" toward which Indiana University is directing its attention: Lincoln, especially origins of the Republican Party and the campaigns of 1856 and 1860 ; Indiana history; the Ohio Valley, I789-I86I, excluding Civil War, slavery, and the Old Northwest; English history and literature, I689-1720, exclusive of the drama, with particular attention to Defoe; the War of 1812 in the West; Livy and Pliny.

Mr. Pargellis reported that the Newberry Library's special interests include: North American Indians; exploration of North and South America (to I800); colonial history of the Americas; Portuguese history (to I820); music, scores, theory, etc.; Arthurian legend; calligraphy; history of typographic arts; pamphlets on the American Revolution, I760-83, both English and American; Civil War (especially regimental histories); eighteenth century correspondence, autobiographies, memoirs, etc., English and American.

After some discussion it was agreed: I. That each person present should draw up a statement showing (a) the principal areas of strength already attained by his library and (b) other areas marked out for special development; 2 . That these statements ideally should approach in fulness and specificity the information a librarian would wish to supply to visiting scholars, but, such full description being lacking, lists would be useful; 3. That each librarian should be responsible for preparing his own materials and for distributing them to all other mem- bers of the group, facilities for manifolding being provided to those in need of them through the gracious offer of Charles $\mathrm{H}$. Brown; 4. That Mr. Brown be asked to undertake the responsibility of following up and consolidating the statements thus prepared.

Mr. Pargellis directed attention to the disintegration of newspaper files for the years $1880-1900$ and inquired what interest those present had in cooperative filming of selected files of Middle Western newspapers for the critical years. Interest being general, it was agreed that each person present send Mr. Pargellis the following: I. A report of steps already taken to film local newspapers; 2. Papers to be considered if cooperative filming proves feasible.

Inquiry into the possibilities of a cooperative scheme for clearing duplicates was assigned to a committee composed of Messrs. Miller (chairman), Pargellis, and Beals.

The following topics, which had been proposed for discussion, were by general agreement laid on the table: cooperative buying in Europe after the war, cooperative buying in general, local or regional deposit libraries, and reproduction of Axis war periodicals.

With respect to future meetings it was agreed: I. That another meeting of the group is desirable; 2. That no formal organization should be set up, the date of the next meeting to be set and the necessary arrangements to be made by a steering committee composed of Messrs. Brown (chairman), White, and Beals.

Ralph A. Beals

Secretary pro tempore

\section{The Use of Records in College Teaching}

\section{(Continued from page 288)}

purchased out of the same funds as books and periodicals. Equipment should come from the same funds that pay for typewriters, catalog cases, etc., while repair and upkeep would be from maintenance. Rental on any materials should come from operating expenses, not book fund. This, of course, if the collection is to be a part of the library which many persons now agree, is the most satisfactory place on a college campus for such a collection. 